\title{
Çapraz Evlilikler ve Gruplar Arası İlişkiler
}

\section{Intermarriages and Relations Between Groups}

\section{Gül ÖZATEŞLER ÜLKÜCAN*}

Öz: Bu makale, farklı kimlik ve kültürel gruplardan bireyler arasında gerçekleşen çapraz evlilik alanındaki çalışmaların önemini göstermeyi amaçlamaktadır. Özellikle ayrıştırıcı toplumsal kategoriler üzerinden konumlanan gruplardan bireylerin evlilik gibi yakın bir ilişkiye girmesi bireylerin ve grupların kimlik algılarını ve ilişkilerini değiştirip temas kurmalarını sağlayabilmektedir. Uluslararası araştırmaların gösterdiği gibi bu evlilikler grup sınırlarının dönüşümüne ve ön yargıların azalmasına da katkı sağlamaktadır. Bu makalede çapraz evlilik araştırmalarının dönüştürücü ve olumlu potansiyelleri, uluslararası ve ulusal literatür gözden geçirilerek tartışılmaktadır.

Anahtar sözcükler: Çapraz Evlilikler, Gruplar Arası Temas, Toplumsal Kategoriler, Kimlik

Abstract: This article aims to demonstrate the significance of intermarriages between individuals from different cultural and identity groups. Specifically, close interactions such as intermarriages between individuals from groups constituted by excluding social categories, that may allow individuals and groups to build contact through changing their perceptions and relations. As international research shows, these marriages contribute to the transformation of group boundaries and diminishing prejudices. In this article, the transformative and positive potentials of intermarriages are discussed by means of an overview of the national and international literature.

Keywords: Intermarriages, Contact between Groups, Social Categories, Identity

Kimlik temelli kutuplaşmalar kimi zaman şiddet olaylarını da kapsayan hiyerarşik, eşitsiz ve ayrıştırıcı ilişkilere yol açabilmektedir. Toplumumuzda da bu tarz kimlik temelli ayrımlar (KürtTürk, Sünni-Alevi ve Çingenelik vb.) anlaşmazlıklar, çatışmalar ve şiddet vakaları ile karşılaşılabilmektedir. Bu durum, akademik ve toplumsal bir sorun olarak ayrıştırıcı ve dışlayıcı kimlik kategorilerinin sorgulanmasını ve kimlik temelli gruplar arası anlaşmazlıklara karşı çözüm yollarının aranmasını gerekli kılmaktadır.

Tüm anlaşmazlıklara rağmen, kimlik temelli kutuplaşan gruplardan bireyler arası evlilikler de mevcuttur. Gruplar arası çapraz evlilikler, gruplar arası toplumsal temasın önemli bir ölçütüdür. Sınırlarını korumak ve grup içi ilişkileri düzenlemek için bireyler arası evlilik ilişkileri topluluğun müdahale ettiği, düzenlediği ve bazı durumlarda tabulaştırdığı bir alan olarak göze çarpmaktadır.

Kültürel farklılıklar, grupların birbirlerine yaklaşımları, duydukları tepkiler ve ön yargılar bu gruplardan bireyler arası evliliği de etkilemektedir. Farklı kimlik kategorileri ile özdeşim kuran birey ve topluluklar arası çapraz evlilikler bize birey ve grup ilişkilerini ve temas geliştirme yollarını sosyolojik olarak çalışmak için faydalı bir alan sunacaktır. Anlaşmazlık ve

\footnotetext{
*Yrd. Doç. Dr., Dokuz Eylül Üniversitesi, Edebiyat Fakültesi, Sosyoloji Bölümü, İzmir. gozatesler@gmail.com
} 
çatışma yerine anlaşma, temas ve kurulan ortaklıkların çalışılması, toplumsal kimlik kategorileri, birey ve grup ilişkileri açısından önemlidir.

$\mathrm{Bu}$ alandaki araştırmalar, çapraz evliliklerin, bireylerle beraber, bireylerin bağlı olduğu gruplar arasındaki ilişkileri, teması, bir arada yaşam pratiklerini ve diyaloğu da geliştirip artırabildiğini göstermektedir. Türkiye'de sayılı çalışmalarla araştırılmaya başlanan bu alan, sosyoloji alanında özellikle gruplar ve bireyler arası ilişkileri anlamak, toplumsal kimlik kategorilerini çözümlemek ve aile sosyolojisi açısından önem taşımaktadır. Bunun yanı sıra sosyal politika alanında, çapraz evlilik oluşturan bireylerin deneyimleri üzerinden anlaşmazlıkların nasıl önlenebileceğine, toplumsal kategoriler ötesi ilişkilerin nasıl kurulduğuna ve böylelikle ayrımcıllğın nasıl aşıldığına dair ipuçları da açığa çıkabilecektir. Böylelikle, birey ve toplum düzeyinde anlaşmazlık ve ayrımcılıkla mücadele etme stratejilerinin de izinin sürülmesi mümkün olabilecektedir. Bu açılardan, bu araştırma alanı toplumsal tabakalaşma, toplumsal kategoriler, toplumsal kimlik, gruplar arası temas ve çapraz evlilik literatürlerine katkı sağlamaktadır. Sosyo-ekonomik açıdan ise farklı birey ve toplulukların belli başlı sorunları ve uğradıkları eşitsizlikler belirlenip ileriye yönelik durum geliştirici sosyal politika projelerine bir yol haritası sunma potansiyeline sahiptir.

Bu gibi potansiyellere sahip bu araştırma alanının Türkiye'deki gelişimine katkı sunmak amacıyla bu makale, bu alandaki belli başlı uluslararası çalışmaların bulgularını sunmayı ve Türkiye'de bu alanda yapılan araştırmaları gözden geçirmeyi hedeflemektedir. Öncelikle çapraz evlilik çalışmalarının toplumsal kimlik kategorileri ve grup ilişkileri ile bağlantısı ortaya konulduktan sonra ileriki bölümde çapraz evliliklerin grup sınırlarını nasıl dönüştürdüğü uluslararası literatür bağlantıları ile tartışılacaktır. Son olarak da Türkiye'de bu alanda yapılan araştırmalar gözden geçirilecektir.

\section{Toplumsal Kimlik Kategorileri ve Grup İlişsileri}

Kimliğe dayalı (etnik, milli, toplumsal cinsiyet, dini vb.) kategoriler, bireyin kimlik algısı ve benlik oluşumunda toplumsal ilişki ve yapılandırmaların öneminin altını çizer ve toplumdaki sosyo-ekonomik ilişkiler ile yakından ilintilidir. Gruplar arası pek çok anlaşmazlık ve şiddet olayları, sosyo-ekonomik çıkar ve kazanımlar ile toplumsal kimlik kategorilerinin ayrıştırıcı işlevlerinin pekiştirilmesi çerçevesinde ortaya çıkabilmektedir (Steinberg 1989; Olzak 1994; Bowen 1996; Bergmann 2002; Van Arkel 2007; Özateşler 2014). Buna karşın, ortak amaçlar etrafinda ve eşit şekilde temas kuran gruplar arasında ön yargılar ve anlaşmazlıklar azalabilmektedir (Forbes 1997).

Sosyal psikoloji alanından, sosyal kimlik teorisi, kimlik kategorilerinin birey ve grup ilişkilerini, ön yargı ve ayrımcılık gibi toplumsal inanış ve algıları nasıl etkilediğini vurgulamasıyla önemli bir literatürü oluşturmaktadır. Kökenleri Henri Tajfel'in çalışmalarına dayanan bu teoride "kategorileştirme", belirli algılar ve rollerle beraber gruplara yönelik basmakalıpların üretilmesine yol açan iki önemli süreçten birisidir (Hogg 1996, 67). Bir diğer süreç olan "kendini yükseltme güdüsü" ise kişinin kendisini ve grubunu öteki kişi ve gruptan daha pozitif algılama eğilimine işaret eder. Bu süreçlere yaptığı vurgu ile sosyal kimlik teorisi sadece bireyin özdeşim kurma mekanizmaları ile değil, aynı zamanda insanlar arası eşitsizliklerin ve güç ilişkilerinin sosyo-psikolojik olarak kurulumuna da dikkat çeker. Bu şekilde sosyal kimlik teorisi, toplumsal alana, ilişkilere ve yapılanmalara, dolayısıyla sosyoloji disiplinine de yakınlaşır (Hogg \& Abrams 1988, 15).

Toplumsal kategoriler üzerinden grup ilişkilerinin analiz edilmesi, sosyoloji alanında etnisite çalışmalarıyla tanınan Hall'un etnisiteyi bir araç olarak kabul etmesi ile benzerlik gösterir. Hall'a göre kimlik stratejik ve konumsaldır ve bu nedenle de farklı konumlara ve ilişki- 
lere göre değişime yatkındır (Hall 1996, 4). Bu alanda çalışan başka bir sosyolog olan Brubaker, benzer bir şekilde, etnisiteye, ırka ve milliyete dayalı kategorileri, esnek ve deneyimle değişen kavramlar olarak görmemizi teklif eder. Brubaker atfedilen bu kategorileri "gruplaşma için potansiyel bir temel" olarak tanımlar (Brubaker 2004, 39).

Etnisiteye, 1rka, milliyete ve dine vb. dayalı kategoriler, sistem meşrulaştırması kuramında (Jost \& Banaji 1994, 2) öne sürüldüğü gibi, basmakalıpların ve ön yargıların oluşumunu da pekiştirerek sistemin olduğu gibi devamına da hizmet edebilmektedir. Fakat gruplar arası kurulan yakın ilişkiler ve temas ile kimlik kategorilerinin ayrıştırıcı özellikleri dönüştürülebilmektedir. Yakın ilişkilerdeki bireyler üzerine yapılan psikolojik çalışmalar, bu kategoriler üzerinden gelişen benlik ve öteki yaratma süreçlerinin dönüştüğünü göstermektedir (Murray 1996; Rusbult et al. 2000 akt. Taluy \& Büyükşahin 2012). Partnerlerin birbirlerinin benliklerini etkiledikleri, sosyal kimlik teorilerinde belirtilen kendini yükseltme güdüsüne paralel olarak partnerlerini de güçlendirerek ilişki doyumlarını arttırdıkları ve benlik imajlarını geliştirdikleri gözlenmektedir. Benzer biçimde, çapraz evlilikler, bireylerin özdeşim kurma mekanizmalarının değişerek halihazırdaki toplumsal kimlik kategorileriyle beraber ön yargıları sorgulayabilecekleri bir alan yaratabilmektedir.

Grup düzeyine baktığımızda ise, Allport'un (1954) geliştirmiş olduğu temas hipotezi kapsamında, kişiselleşmiş ve eşit bir şekilde kurulan ilişkiler üzerinden temasın ön yargıları azaltacağ1 vurgulanmıştır (Dovidio et al. 1997). Bu süreç kategorisizleştirme (decategorization), tekrar kategorileştirme (recategorization) ve alt kategorileştirme (subcategorization) olarak işlemektedir ve verili kategorilerin dönüşümüne yol açmaktadır (Brewer 1996; Dovidio et al. 1997). Etnisite ve 1rk çalışmalarında öne çıkan sosyologlar olan Alba ve Nee (2003) benzer bir dönüşümü Birleşik Devletler'deki asimilasyon sürecini incelediklerinde de fark etmişlerdir. Alba ve Nee etnik gruplar arasındaki sınırların zaman içinde aşılma, silikleşme ve yer değiştirme gibi dönüşüm süreçlerinden geçtiklerini belirtmişlerdir. Sınır aşma, bir bireyin diğer grubu kabulü şeklinde gerçekleşirken, silikleşme gruplar arasındaki etnik farklılıkların netliğini yitirmesi ve grup sınırlarının belirsizliğine işaret eder. Sınırların yer değiştirmesi ise, öteki konumundaki bir grubun yeni bir kapsayıc kategoriye dahil edilmesi şeklinde olur.

Toplumsal kimlik kategorilerindeki ve grup ilişkilerindeki dönüşümler, çapraz evlilikler üzerine yapılan çalışmalarda net bir şekilde ortaya konulmuştur. Farklı kültür ve kimlik gruplarından gelen bireyler, evlilik gibi kurdukları yakın ilişkilerde kendi kimlik algılarını, eşlerinin kimlik algılarını ve bağlı oldukları grupların birbirlerini algılayışları ve ilişkileri ile birlikte kimlik kategorilerinin ve grupların sınırlarını dönüştürebilmektedir.

\section{Çapraz Evlilikler ve Grup Sınırlarının Dönüşümü}

Yakın ve çoğunlukla uzun süreli niyetlenilen, hem bireyleri hem de içinde bulundukları grupları aile ve akrabalık ilişkileriyle birbirine bağlayan bir ilişki olan evlilik, toplumsal kategoriler üzerinden ayrışan gruplardan olan bireyler arasında gerçekleştiğinde, dönüştürücü ve ilginç sonuçlar vermektedir. Öncelikle, farklı kimlik gruplarından bireyler arası evlilik (çapraz evlilik), grup sınırlarına ve kimlik kategorilerine karşın gruplar arası etkileşimi ve bireylerin birbirlerini toplumsal olarak denk gördüğünü gösterir (Kalmijn 1998). Bu, yukarıda değinilen sosyal temas hipotezinde öngörüldügü gibi teması arttırıcı bir koşuldur. Bu evlilikler ön yargı ve basmakalıpları azaltıcı potansiyellere de sahiptir. Çapraz evlilikle bireyler diğer gruba karşı duyduğu negatif tavırlardan kurtulabilirler. Kalmijn (1998), çapraz evlilikler sonucu toplumda ve gruplar arası ilişkilerde nasıl değişiklikler olduğunu sıralarken sosyal kimlik kuramında değinilen kategorilerin etkilerinin azaldığına dikkat çeker. Çapraz evliliğin bir ortak sonucu, gelecek nesiller için kültürel farklılıkların ayrıştırıcı özelliğinin azalmasına ve bu ailelerdeki çocukların tek bir grupla özde- 
şim kurmamalarına dayanır.

Çapraz evlilik çalışmaları özellikle 'ırklar' arası evlilikler de dahil pek çok farklı kültür, grup ve kimliği bünyesinde barındıran ve bu alandaki çalışmalara önem veren Amerikan sosyal bilimcileri arasında yoğunlaşmışıı. Bu evliliklerin hangi bireyler arasında daha kolay kurulduğu, bu evliliklerde eşler arası kurulan bağ ve iletişim biçimleri, kimlik algılarının dönüşümü, çocukların özdeşim biçimleri gibi konular öncelikle sosyologlar, psikologlar ve davranış bilimciler tarafından çalışılmaktadır. Gruplar arası sınırların muğlaklaşması ve çok kültürlü özdeşimler, çapraz evlilikler üzerine yapılan çalışmaların önemli bulguları arasındadır (Stephan \& Stephan 1989; Feliciano 2001; Alba \& Nee 2003; Monden \& Smits 2005). Çapraz evlilik üzerine yapılan çalışmalar, çoğunlukla göçmenlerin birbirleriyle ve nüfusun geri kalanıyla kurdukları ilişkileri incelemekte, kültürler arası asimilasyon olasılıklarını araştırmakta ve gruplar arası geçişliliği sorgulamaktadır.

Kültürler arası evlilikler sonucu doğmuş olan bireyler çok kültürlü özdeşimler kurabilmekte ve kendilerini birden fazla kültür içerisinde tanımlayabilmektedirler. Örneğin, gruplar arasındaki çapraz evlilikler sonucu karma mirasa sahip yarı-Japon ve yarı-İspaniklerle yapılan bir araştırma, yarı-Japonların \%73'ünün yarı-İspanik'lerin ise \%44'ünün çoklu etnik kimlik geliştirdiklerini ortaya koymuştur (Stephan \& Stephan 1989). Bunun yanı sıra, çapraz evlilikle olmuş çocuklar da kendi etnik grupları dışında evlenmeye eğilim gösterebilmektedir (Stephan \& Stephan 1989, 508). Çapraz evlilikler bu etkileriyle de birlikte gruplar arası sınırların belli durumlarda ortadan kalkmasına katkıda bulunmaktadır (Feliciano 2001; Alba \& Nee 2003; Monden \& Smits 2005). Çapraz evlilikte bulunan bireyler de kimliklerini ilişkileri içerisinden tekrar tanımlayıp kendi özdeşimlerini ve benliklerini çoğul bir şekilde kurabilmektedir (Luke \& Luke 1998, 743; Foeman \& Nance 2010, 243).

$\mathrm{Bu}$ evlilikler, gruplar arası sinırları esnetmekle birlikte gruplar arası teması da arttırırlar. Bireyler kendi yakın çevrelerini bir araya getirerek ilişkileri artırmakta ve ön yargıların azalmasına katkıda bulunmaktadır. Irksal ve etnik olarak belirlenmiş sınırları aşan evlilikler, toplumsal uzaklık kurallarına meydan okuyabilmektedir (Lee \& Fernandez 1998, 324). Örneğin Amerika'da 1970'ten beri artan farklı kimlik gruplarından bireyler arası çapraz evlilikler, grup sınırlarının zayıflamasına ve gruplar arası toplumsal uzaklığın azalmasına sebep olmuştur (Rosenfeld 2002; Qian \& Lichter 2007) Özellikle göçmen grupların topluma entegrasyonu ve asimilasyonu üzerine yapılan çalışmalar çapraz evliliklerin asimilasyonu da arttırdığını göstermektedir (Rosenfeld 2002; Qian \& Lichter 2007; Song 2009). Gruplar arası şiddet olaylarının da gruplar arası kurulan evliliklerin yarattığı temasla aşılabileceği düşünülmektedir (Smits 2010).

Bununla beraber, çapraz evlilikler, sosyo-ekonomik faktörler, toplumsal politikalar, tarihsel süreçler gibi etkenler içerisinde dönüşebilmektedir. Özellikle farklı din gruplarından bireyler arasında yapılan evliliklere bakıldığında sekülerleşme kuramı, sanayileşme ve kentleşmenin dini pratikler ve inançların insanların hayatlarını yönetmedeki önemini azaltarak dine dayalı toplumsal sınırları azalttığını vurgulamıştır (Kalmijn 1991, 788). Aile değerleri arasındaki farkların azalması, ailelerin modernleşip evlilik kararının ebeveynlerinden çok ekonomik bağımsızlığını kazanan birey tarafından alınmaya başlanması; kentleşmenin ve eğitimin artmasının etkisi ile insanların daha heterojen topluluklarda yaşaması gibi faktörler de çapraz evliliklerin artmasında ve bu evliliklerdeki sorunların azalmasında etkili olmuştur (Kalmijn 1991, 788-791). Bu değişiklikler eğitim gibi başka bir faktörün ortaklık kurma mekanizmalarında öne çıkmasını sağlayabilmektedir.

Bunun yanı sıra, farklı grupların çapraz evliliğe açıklık ve kapalılıkları da değişebilmektedir. Mesela Amerika'da yapılan çalışmalar göstermektedir ki Latinler ve Asyalılar AfroAmerikalılardan daha fazla oranda, Avrupalılar ise onlardan da daha fazla oranda çapraz evlilik 
yapmaktadır (Feliciano 2001; Qian \& Lichter 2007). Başka bir çalışmada Latvialılar ile Ruslar arasındaki evlilik eğilimlerini inceleyen Smits ve Monden (2005) çapraz evliliklerin daha az eğitimlilerde, çapraz evlilik sonucu olan çocuklar arasında, aynı eğitim seviyesinde ve kırsal alanda daha fazla gerçekleştiğini gözlemliyor. Bununla beraber, toplulukların kendi içlerindeki büyüklügü, göç hareketleri ve gruplar arası toplumsal uzaklık gibi faktörler çapraz evlilikleri etkilemektedir (Lee \& Fernandez 1998; Qian \& Lichter 2007). Küçük gruplar için grup diş1 evlilik olasılığı artmaktadır. Topluluklar arası uzaklı̆̆ın azlığı, ayrımcılık ve dışlanma gibi pratiklerin olmaması da çapraz evliliği arttırıcı niteliktedir.

Kurulan teması vurgulayan çalışmalara rağmen şüphesiz bu evliliklerdeki bireyler, gruplar arası farkl11ıklardan olumsuz yönde etkilenip anlaşmazlıklar da yaşayabilmektedir. Evlilik literatürü, anlaşmazlıkların tüm evliliklerin ayrılmaz bir parçası olduğunu belirtmektedir (Fincham 2003). Buna karşın, bazı çalışmalar gruplar arası evliliklerde, grup içi evliliklere kıyasla daha fazla anlaşmazlık ve boşanma riskinin olduğunu belirtmektedir (Gaines \& Ickes 1997; Bramlett \& Mosher 2002; Zhang \& Van Hook 2009; Kang Fu \& Wolfinger 2011). Bunun aksine, başka çalışmalar da bu ilişkilerde dışarıdan gelen ön yargılara karşı birbirlerine tutunup ayrı bir "biz" oluşturan çiftlerin birbirleriyle kurdukları yakın bağları ortaya koymaktadır (Henderson 2010; Seshadri \& Knudson-Martin 2013). Bu açllardan, bu çalışmalarda kültürel farklılıkların, ön yargı ve basmakalıpların bireyler arası anlaşmazlıkları ne şekilde etkilediğini görmek kadar, bireylerin bu anlaşmazlıklarla nasıl mücadele edip evliliklerini devam ettirebildikleri de önem kazanmaktadır.

Henderson çapraz evlilik yapan çiftlerin kendi aralarındaki sorunların yanı sıra toplumsal damga ile de mücadele etme durumunda kaldıklarını belirtmiştir (Henderson 2010, 422). Seshadri ve Knudson-Martin, çalışmalarında çapraz evlilik yapan çiftlerde 4 ana ilişki yapısı belirlemişlerdir. Bunlar, bütünleşmiş (kültürel farklılıkları, kültürleri birbiri içinde eritip her ikisini de kutlayarak karşılayan), bir arada var olan (farklılıkları pozitif olarak algılayıp kültürel farklılıklar1 koruyan), tek yönlü asimile olmuş (bir eşin diğerinin kültürüne asimile olması) ve çözümlenememiş (bireylerin birbirlerinin farklılığıyla nasıl başa çıkacağını bilememesi ve anlaşmazlık yaşaması) çiftler olarak ortaya çıkmıştır. Seshadri ve Knudson-Martin, evliliklerini devam ettirme ve anlaşmazlıklarla başa çıkma stratejileri olarak çiftler için kültürel farklılıkları aşan bir "biz yaratma" ve "kendi ortaklıklarını kurma"; "farklılıklarını olumlu bir şekilde çerçeveleme", "farklılıklarına saygı duyup esnek davranmaya çalı̧̧ma"; "diğer insanlarla görüşürken güvensizlikleri için birbirlerine destek olma"; "beraberliklerini ait oldukları aile ve arkadaş gruplarında var edebilme" gibi yolların önemli olduğunu söylemişlerdir (2013, 53-55). Henderson $(2010,429)$ da diğer çiftlerin uğraştıkları pratik mevzulardan farklı olarak, ön yarg1 ve dışarıdan gelen tepkilere karşı, çapraz evlilikteki çiftlerin evliliklerini korumak adına bir duvar oluşturduklarını gözlemlemiştir. Bazı araştırmalar, dış faktörlere karşı duygusal bağlılıklarını arttırıp daha güçlü bir ilişki kurdukları sonucuna da varmıştır (Luke \& Luke 1998, 745; Henderson 2010, 435; Foeman \& Nance 2010, 244).

$\mathrm{Bu}$ şekilde, çapraz evliliklerin birey ve grup ilişkilerine etkileri, toplumsal kategori ve grup sınırlarını ne şekilde dönüştürdüğü ve bireylerin toplumsal ön yargılara ve ayrımcılık deneyimlerine rağmen nasıl evliliklerini sürdürebildikleri gibi pek çok alanda araştırmayı kapsayan çapraz evlilik çalışmaları toplumsal analizler için önemli veriler sunmaktadır. Grup uzaklıkları, sosyal politikaların etkileri, makro düzeydeki değişimlerin grup ve birey hayatlarına yansımaları gibi pek çok toplumsal süreç çapraz evlilik araştırmalarında gözlenebilmektedir. 


\section{Türkiye'de Çapraz Evlilikler Üzerine Çalışmalar}

Türkiye'ye baktığımızda ise evliliğin sadece bireyler arası bir ilişkiyi değil, aynı zamanda gruplar arası ilişkiyi de gösterdiği belirgin bir yer edinmektedir. Öyleki geleneksel olarak eş seçimi bazı durumlarda evlenen çiftleri tamamen sürecin dişında bırakarak geniş ailenin tercih, istek ve belirlemelerine göre yapılabilmektedir (Ilcan 1994, 274). Gruplar arası ilişki açısından bu denli önemli olmasına rağmen farklı gruplardan bireyler arası çapraz evlilik üzerine sınırlı sayıda çalışma bulunmaktadır. Aile ve evlilik üzerine yapılan çalışmalar, özellikle ilişkilerin zamanla nasıl dönüştüğü, aile kurumunun geniş aile yapısından çekirdek aile yapısına evrilmesi ve toplumsal dönüşüme bağlı olarak yapılmıştır (Örn. Duben \& Behar 1996; Özbay 1998; Aytaç 2012). Bu açıdan evlilik, köy monografilerinde, göç ve kentleşme olgularının çalışılmasında akrabalık ilişkileri ile birlikte değişen etkenlerden biri olarak ele alınmıştır (Altuntek 2001, 17)

Türkiye'de çapraz evlilik üzerine başvurulan başlıca çalışmalardan biri 1992'de özel bir araştırma şirketi (KONDA) tarafından yapılan araştırmadır. Bir diğeri ise Gündüz-Hoşgör ve Smiths (2002) tarafından 1993 ve 1998'teki Türk Sağlık ve Nüfus İstatistikleri üzerinden yapılan araştırmadır. Bu iki çalışma, Türk-Kürt evliliklerinin oranını; mesleki, sınıfsal ve coğrafi faktörlerin bu orana etkisini ortaya koymaya çalışmaktadır. Bu çalışmalara göre Türk-Kürt evliliklerinin genel eğilimi Türk kadınlarla Kürt erkekler arasında yapılmasıdır. Gültekin (2012), bu iki çalışma üzerine yaptığı değerlendirmede Kürt kadınlarının çapraz evliliklerdeki az oranını hala güçlü olan yarı-feodal değerler sistemine ve onları akrabalarının himayesinde ve ev içinde tutan kültürel biçimlere dayandırıyor (Gültekin 2012, 156). Bu toplumsal şartlarda kapalı topluluk yapısındaki Kürtlerden öncelikli olarak erkekler modern devlet sistemiyle ilişki kurup eğitim alırken Kürt kadınları topluluğun namusunun simgesi ve ataerkil aile yapısının sonucu olarak ev/topluluk içinde tutuluyor. Devletin sağladığı eğitimle modern toplumsal statü ve ekonomik güç sağlamalarının yolu açılan Kürt erkeklerinin ise Kürt olmayan topluluklarla evlilik ilişkileri artıyor (Gültekin 2012, 156-157)

Bununla beraber eğitim seviyesi yükselen Kürt erkeklerinin kendi eğitim seviyelerine denk Kürt bir kadını zorlukla bulması da eşlerini Kürt olmayan kadınlardan seçmelerine neden olabiliyor (Gültekin 2012, 157). Hoşgör ve Smits (2002) Türkiye'deki eğitim seviyesinin etnik farkl1lıklarla paralellik gösterdiğini ve Türkler arasındaki eğitim düzeyinin Kürtler arasındakinden daha farklı olduğunu vurguluyor. Bunun yanı sıra kendi etnik grubundan yapılan eş seçiminin de kendi eğitim grubuna yönelmenin bir yan ürünü olduğunu belirtiyor. Ayrıca, Kürt kadınlarının geniş bir çoğunluğu hiç okula gidemeyebiliyor ve Türkçe konuşamayabiliyor (GündüzHoşgör \& Smits 2002, 421). Hoşgör ve Smits Kürt erkeklerinin \%25'e yakın bir bölümünün ilkokul öğrenimini tamamlamadığını bu oranın kadınlarda \%70'e çıktığını gösteriyor. Türklerde bu oranlar \%7 ve \%22 olarak gözüküyor (Gündüz-Hoşgör \& Smits 2002, 424). Türklerde eğitim seviyesi en düşükler daha fazla Kürt eşle evlenmeye eğilim gösterirken Kürtlerde eğitim seviyesi en yüksek olanlar en yüksek grup dışı evlilik oranlarını sergiliyor.

Hoşgör ve Smits 1990'larda Türkler arasında başka bir etnik gruptan evlenme oranının \%2 ve bunun \%1.4'ünün Kürtlerle olduğunu söylüyor. Kürtlerde ise etnik grup dışı evlenme oranı $\% 10$ 'a, Türklerle evlenme oranı ise $\% 8.4$ 'e çıkıyor. Bu durumdaki fark Türklerin sayısının daha fazla olmasıyla açıklanıyor. Kürtler için grup dışı evlenme coğrafi olarak en düşük oranda ülkenin doğusunda bulunmaktadır (Gündüz-Hoşgör \& Smits 2002, 426). Türkler için ise Doğu'da bulunanlar arasında Kürtlerle evlilik daha çok gözlenmektedir. Hoşgör ve Smits bunu kendi gruplarının büyüklüğü az olan yerlerde bireylerin grup dışına daha fazla yönelmesiyle açıklıyor. Şehirleşmeye göre oluşan farklılıklara bakıldığında büyük şehirler ve başkentte evli Kürtlerin \%25'inin Türk eşi var iken bu oran kırsal alanlarda \%5'e düşüyor. Türkler için ise kırsal alanlarda yaşayanlar daha az grup dışı evlilik yapsa da oranlar arasındaki fark o denli yüksek 
olmuyor ve \%1.5 civarında kalıyor (Gündüz-Hoşgör \& Smits 2002, 426-427).

Uluslararası çalışmaları destekler biçimde iki grup için de gruplar arası evlilik yapmış bir ailede büyümenin grup dışı evlilik eğilimini çok büyük bir oranda etkilediği göze çarpıyor (Gündüz-Hoşgör \& Smits 2002). Karma aile yapısındaki Türklerin neredeyse üçte biri, Kürtlerin ise \%40'ı başka bir gruptan birisiyle evleniyor. Hoşgör ve Smits Türkler için Kürt bir eşle evlenme eğiliminin 1990'larda artmış olduğunu belirtmektedir. 1993 ile 1998 araştırmalarını kıyasladıklarında da daha fazla Türk'ün Kürt eş seçtiğini vurgulamaktalar. Mersin Üniversitesi'nin 2000 kişi ile 1998, 2002, 2007 ve 2010'da yaptığı bir araştırma ise Kürtler ve Türkler arasındaki uzaklığın arttığını ve 1998 'de Türklerin \%26.9'u Kürt eş seçebileceklerini belirtirken bu oran 2010'da \%1.3'e düştüğünü belirtiyor (T24 Bağımsız İnternet Gazetesi,14 Aralık 2010, http://t24.com.tr/haber/kurt-ve-turk-evliligi-bitiyor-mu,116721, son erişim tarihi: 08Aral1k2014). Aynı dönemler için Kürtlerin Türk eş seçme eğilimi ise \%12.8'den \%0'a düşüyor.

Türkiye'deki çapraz evlilikler üzerine yapılan az sayıda çalışmalara bir ek Balkanlığlu'nun (2012) Alevi ve Sünni aileleri arasındaki evliliklere baktığı çalışmadır. Balkanlıŏlu çapraz evlilik oluşturan çiftlerin sosyal damgalamayla başa çıkma durumlarına dikkat çekmektedir. Pek çok çift, en yakın aile bireylerinden bile tepki görmektedir ve evlilikleri aile, akraba ve arkadaş ilişkilerini etkilemektedir. Bu açıdan Alevi-Sünni çiftler, sosyal damgalanmaya maruz kalmakta ve ilişkilerinde olumsuzluklarla mücadele etmeleri gerekmektedir (Balkanlığlu 2012, 178). Türkiye'de bu alanda yazılı başka bir eser olan Aytav'ın (2012) eseri de bilimsel bir analiz yapmamakla beraber bu evliliklerin aile ve toplumdan gelen sert tepkiler, uyumsuzluk ve endişe kaynağı olarak algılanma gibi problemle karşılaştığını ancak başarılı olduklarında ön yargıların kırılmasına ve toplulukların birbirlerini daha yakından tanımasına imkan verdiğini belirtmiştir (2012, 112-113). Aytav (2012), Alevi-Sünni çiftlerle yaptığ1 görüşmeleri sunduğu eserinde bu evliliklerin artışında uluslararası literatürdeki bulgulara benzer bir şekilde (Kalmijn 1991) kentleşmenin ve eğitimin etkisinin önemli olduğunu göstermiştir.

Son derece sınırlı bir alan olarak çalışılan çapraz evlilikler, Türkiye'de birkaç araştırmanın dışında ele alınmamıştır. $\mathrm{Bu}$ alanda kapsamlı, güncel nitel ve nicel verileri sunabilecek araştırmalar, Türkiye'deki birey ve grup ilişkileri, bu ilişkileri etkileyen faktörler, ön yargı ve gruplar arası uzaklık, toplumsal kimlik kategorileri ve özdeşim mekanizmaları gibi sosyolojik alanlarda önemli veriler sunma potansiyelindedir. Bu açılardan ulusal ve uluslararası literatürlere sunacakları katkılarla beraber bu çalışmalar, birey ve grupların barışçıl bir şekilde kurdukları temasları ortaya çıkarmakla, ön yargıların azalması ve ayrımcılık ile mücadelenin güçlenmesi gibi sosyal politika alanlarında da etkili olacaktır.

\section{Sonuç}

Türkiye'de farklı gruplar arası evlilikler olmasına karşın henüz akademik olarak kapsamlı bir araştırma yapılmamıştır. Bu alanda yapılacak çalışmalar uluslararası örneklerinde olduğu gibi akademik, sosyal ve siyasal açılardan çeşitli katkılar sunabileceklerdir.

Öncelikle bu evlilikler üzerine yapılan çalışmalar, özdeşim kurma mekanizmalarının ne şekilde değişebildiğini ve kimlik kategorilerinin dönüşümünü açığa çıkarmaktadır. Bununla beraber katı ve değişmez kimlik kategorileri sorgulanabilmekte, ön yargı ve basmakalıp düşünceler gözden geçirilebilmekte ve gruplar arası sınırlar yeniden tanımlanabilmektedir. Bireylerin anlaşmazlık çözümlerindeki deneyim ve stratejilerine bakılarak gruplar arası temasın nasıl geliştirilebildiği de ortaya çıkabilmektedir.

Türkiye, farklı grupların barışçıl bir şekilde bir arada yaşamasına güzel örnekler sergileyebilirken, ne yazık ki bir takım anlaşmazlık ve ayrımcılık örneklerine de halen ev sahipliği yapabilmektedir. Türkiye'de gerçekleşen çapraz evlilikler alanında yapılacak çalışmalar hem 
gruplar arası ilişkilerin bireyler üzerinden ne şekilde kurulabildiği hem de ne gibi ön yarg1 ve anlaşmazlıklarla nasıl başa çıkıldığını gösterebilecektir. Bu açılardan grup ilişkilerinin geliştirilebilmesi, uzaklıkların azaltılıp temas ve diyalogların geliştirilebilmesi için bu alanda araştırmaların artması toplumsal barışa da katkı sunabilecektir.

\section{KAYNAKÇA}

Alba R. \& Nee V. (2003). Remaking the American Mainstream. Cambridge 2003.

Altuntek S. (2001). "Türkiye Üzerine Yapılmış Evlilik ve Akrabalık Araştırmalarının Bir Değerlendirilmesi”. Hacettepe Üniversitesi Edebiyat Fakültesi Dergisi 18/ 2 (2001) 17-28.

Aytaç A. M. (2012). "Türkiye'de Ailenin Tarihsel Dönüşümü: 1925-2010”. Eds. F. Alpkaya \& B. Duru. 1920 'den Günümüze Türkiye'de Toplumsal Yapı ve Değişim (2012) 299-322. Ankara.

Aytav E. T. (2012). Alevi-Sünni Evlilikler: Sevdim Seni Bir Kere. İstanbul 2012.

Balkanlığlu M. A. (2012). “Alevi-Sünni Evliliklerinin Aile İlişkileri ile Çocuk Yetiştirme Üzerine Etkileri ve Sosyal Damgalama”. Türk Kültürü ve Hacı Bektaş Veli Araşstırma Dergisi 62 (2012) 163-182.

Bergmann W. (2002). "Exclusionary Riots: Some Theoretical Considerations". Eds: C. Hoffmann, W. Bergmann \& H. W. Smith. Exclusionary Violence (2002) 161-185. Michigan.

Bowen J. R. (1996). "The Myth of Global Ethnic Conflict”. Journal of Democracy 7/4 (1996) 3-14.

Bramlett M. D. \& Mosher W. D. (2002). Cohabitation, Marriage, Divorce, and Remarriage in the United States. Vol. 23. Hyattsville 2002.

Brewer M. (1996). "When Contact is not Enough: Social Identity and Intergroup Cooperation". International Journal of Intercultural Relations 20/3-4 (1996) 291-303.

Brubaker R. (2004). Ethnicity Without Groups. Cambridge 2004.

Dovidio J. F. \& Gaertner S. L. (1997). "Extending the Benefits of Recategorization: Evaluations, SelfDisclosure, and Helping". Journal of Experimental Social Psychology 33 (1997) 401-420.

Duben A. \& Behar C. (1996). İstanbul Haneleri: Evlilik, Aile ve Doğurganlık 1880-1940. İstanbul 1996.

Feliciano C. (2001). "Assimilation or Enduring Racial Boundaries? Generational Differences in Intermarriage Among Asians and Latinos in the United States". Race and Society 4 (2001) 27-45.

Fincham F. D. (2003). "Marital Conflict: Correlates, Structure and Context". Current Directions in Psychological Science 12/1(2003) 23-27.

Foeman A. \& Nance T. (2010). "Building New Cultures, Reframing Old Images: Success Strategies of Interracial Couples". Howard Journal of Communications 13/3 (2010) 237-249.

Forbes H. D. (1997). Ethnic Conflict: Commerce, Culture and the Contact Hypothesis. New Haven 1997.

Gaines S. O. Jr. \& Ickes W. (1997). "Perspectives on Interracial Relationships". Ed. S. Duck. Handbook of Personal Relationships: Theory, Research and Interventions (1997) 197-220. Chichester.

Gültekin M. N. (2012). "Debates on Inter-Ethnic Marriages: Assimilation or Integration?”. The Turkish Perspective Papers 97/1 (2012) 151-166.

Gündüz-Hoşgör A. \& Smits J. (2002). "Intermarriage Between Turks and Kurds in Contemporary Turkey: Inter-Ethnic Relations in an Urbanizing Environment”. European Sociological Review 18/4 (2002) 417-432.

Hall S. (1996). "Introduction Who Needs Identity”. Eds. S. Hall \& P. Gay. Cultural Identity (1996) 1-17. London, New Delhi.

Henderson D. A. (2000). "Racial/Ethnic Intermarries Couples and Marital Interaction: Marital Issues and Problem Solving”. Sociological Focus 33/ 4 (2000) 421-438.

Hogg M. A. \& Abrams D. (1988). Social Identification: A Social Psychology of Intergroup Relations and Group Processes. London, New York 1988.

Hogg M. A. (1996). "Intragroup Processes, Group Structure and Social Identity”. Ed. W. P. Robinson. Social Groups and Identities: Developing the Legacy of Henri Tajfel (1996) 65-94. Oxford.

Ilcan S. M. (1994). "Marriage Regulation and the Rhetoric of Alliance in Northwestern Turkey". Ethnology 33/4 (1994) 273-296. 
Kalmijn M. (1991). "Shifting Boundaries: Trends in Religious and Educational Homogamy". American Sociological Review 56/6 (1991) 786-800.

Kalmijn M. (1998). "Intermarriage and Homogamy: Causes, Patterns, Trends". Annual Review of Sociology 24 (1998) 395-421.

Kang Fu V. \& Wolfinger N. H. (2011). "Broken Boundaries or Broken Marriages? Racial Intermarriage and Divorce in the United States". Social Science Quarterly 92/4 (2011) 1096-1117.

Lee M. S. \& Fernandez M. (1998). "Trends in Asian American Racial/Ethnic Intermarriage: A Comparison of 1980 and 1990 Census Data". Sociological Perspectives 41/2 (1998) 323-342.

Luke C. \& Luke A. (1998). "Interracial Families: Difference Within Difference". Ethnic and Racial Studies 21/4 (1998) 728-754.

Monden C. W. S. \& Smits J. (2005). "Ethnic Intermarriage in Times of Social Change: The Case of Latvia". Demography 42/2 (2005) 323-345.

Olzak S. (1994). The Dynamics of Ethnic Competition and Conflicts. Stanford 1994.

Özateşler G. (2014). Gypsy Stigma and Exclusion in Turkey, 1970: The Social Dynamics of Exclusionary Violence. New York 2014.

Özbay F. (1998). "Türkiye'de Aile ve Hane Yapısı: Dün, Bugün, Yarın”. Ed. A. B. Hacımirzaoğlu. 75 Yllda Kadinlar ve Erkekler (1998) 155-172. İstanbul.

Rosenfeld M. J. (2002). "Measures of Assimilation in the Marriage Market: Mexican Americans 19701990". Journal of Marriage and Family 64 (2002) 152-162.

Qian Z. \& Lichter D. T. (2007). "Social Boundaries and Marital Assimilation: Interpreting Trends in Racial and Ethnic Marriage". American Sociological Review 72 (2007) 68-94.

Seshadri G. \& Knudson-Martin C. (2013). "How Couples Manage Interracial and Intercultural Difference: Implications for Clinical Practice". Journal of Marital and Family Therapy 39/1 (2013) 43-58.

Smits J. (2010). "Ethnic Intermarriage and Social Cohesion. What Can We Learn from Yugoslavia?". Social Indicators Research 96/3 (2010) 417-432.

Steinberg S. (1989). The Ethnic Myth: Race, Ethnicity and Class in America. Boston 1989.

Stephan C. W. \& Stephan W. G. (1989). "After Intermarriage: Ethnic Identity Among Mixed Heritage Japanese-Americans and Hispanics". Journal of Marriage and Family 51 (1989) 507-519.

T24 Bağımsız İnternet Gazetesi (2010, Aralık 14). Türk ve Kürt Evliliği Bitiyor mu? Kaynak: http://t24.com.tr/haber/kurt-ve-turk-evliligi-bitiyor-mu,116721. Erişim Tarihi: 08 Aralık 2014.

Taluy N. \& Sunal A. B. (2012). "Yakın İlişkilerde Michelangelo Olgusu: İdeal Benliğin Heykeltıraş1 Olarak Partner Onaylaması". Türk Psikoloji Yazıları 15/29 (2012) 57- 65.

Van Arkel D. (2009). The Drawing of the Mark of Cain: A Socio-Historical Analysis of the Growth of Anti-Jewish Stereotypes. Amsterdam 2009.

Zhang Y. \& Van Hook J. (2009). "Marital Dissolution Among Interracial Couples". Journal of Marriage and Family 71 (2009) 95-107. 
